PERM JOURNAL OF PETROLEUM AND MINING ENGINEERING ВЕСТНИК ПНИПУ. ГЕОЛОГИЯ. НЕФТЕЕАЗОВОЕ И ГОРНОЕ ДЕЛО

ISSN 2224-9923

Volume/ Tom 16 №3 2017

http://vestnik-pstu.ru/geo/

УДК 622.363:622.831.32

Article / Статья

(C) PNRPU / ПНИПУ, 2017

\title{
ABOUT THE MECHANISM OF LOCALIZATION OF GAS DYNAMIC PHENOMENA FOCUSES IN THE BEDROCK OF SYLVINITE FORMATIONS
}

\section{Aleksandr A. Baryakh, Sergey S. Andreyko ${ }^{1}$, Anton K. Fedoseev}

Federal State Budgetary Institution of Science Perm Federal Research Center of the Ural Branch of the Russian Academy of Sciences (78 Sibirskaya st., Building A, Perm, 614007, Russian Federation)

${ }^{1}$ Perm National Research Polytechnic University (29 Komsomolskiy av., Perm, 614990, Russian Federation)

\section{О МЕХАНИЗМЕ ЛОКАЛИЗАЦИИ ОЧАГОВ ГАЗОДИНАМИЧЕСКИХ ЯВЛЕНИЙ В ПОЧВЕ СИЛЬВИНИТОВЫХ ПЛАСТОВ}

\section{А.Б. Барях, С.С. Андрейко ${ }^{1}$, А.К. Федосеев}

Федеральное государственное бюджетное учреждение науки Пермский федеральный исследовательский центр Уральского отделения Российской академии наук (614007, Россия, г. Пермь, ул. Сибирская, 78a)

${ }^{1}$ Пермский национальный исследовательский политехнический университет (614990, Россия, г. Пермь, Комсомольский пр., 29)

Received / Получена: 07.06.2017. Accepted / Принята: 18.07.2017. Published / Опубликована: 15.09.2017

Key words:

Starobinsk field, potash

mines, mine excavations, potash formation, gas dynamic phenomena, sudden salt and gas emission, long face, stressstrain state, rocks, halite, contact elements, mathematical modelling, collapse criteria, plastic deformations, clay interbedding, mine works, finite element method, numerical modelling.

\begin{abstract}
Results of geomechanical modelling of a stress-strain state of salt rocks in conditions of layer mining at mines of Belaruskali JSC are reviewed. There are sudden powerful gas dynamic phenomena (GDP) occur from the bedrock of mines such as salt and gas emission, bedrock destruction followed by gas release. Moreover, there are areas that are potentially dangerous due to gas dynamic phenomena acting from the bedrocks. For the conditions of the Starobinsk deposit of potassium salts gas accumulations in bedrocks of mines are usually confined to clayish interlayers and layers in salt rocks. Therefore, it is assumed that disclosure of clay contacts is a geomechanical prerequisite for GDP. That leads to formation of channels for migration of free gases and formation of artificial gas-saturated zones under the influence of mining operations.

Task statement includes setting of parameters for collapse of the roof rocks of the Third potash formation being under the mining, localization of plastic deformations in the enclosing rocks and opening of clay contacts in a salt thickness. It is taken into account that collapsed rocks of a long face roof fill the goaf and form technogenic geo-environment with respect to their decompaction. The geo-environment is also included in the calculation scheme of mathematical modeling. In order to determine a stress-strain state of rocks, a model of an ideal elastic plastic medium with internal friction is used. In this case, clay interbedding are described by Goodman's contact elements

Based on results of solution of a number of model problems in a two-dimensional statement, there is a conclusion made on the significant influence of clay interbedding in the bedrocks of a formation under the mining on the possibility of occurrence of gas dynamic phenomena. It is established, that in presence of three and more clay contacts in the layer of underlying halite there are conditions created for formation of a multi-stage focus of GDP, formed when gas-saturated clay contacts are exposed. Periodic character of formation of GDP focuses is noted during the movement of the front of cleaning works.
\end{abstract}

\section{Ключевые слова:}

Старобинское месторождение, калийные рудники, горные выработки, калийный пласт, газодинамические явления, внезапные выбросы соли и газа, лава, напряженно-

деформированное состояние, горные породы, каменная соль, контактные элементы, математическое моделирование, критерии обрушения, пластические деформации, глинистые прослои, горные работы, метод конечных элементов, численное моделирование.

\begin{abstract}
Рассматриваются результаты геомеханического моделирования напряженно-деформированного состояния соляных пород в условиях слоевой выемки на рудниках ОАО «Беларуськалий», где из пород почвы горных выработок происходят внезапные, достаточно мощные газодинамические явления (ГДЯ) в виде выбросов соли и газа, разрушений пород почвы, сопровождающихся газовыделениями. Там же выявляются участки, потенциально опасные по газодинамическим явлениям из почвы. Для условий Старобинского месторождения калийных солей газовые скопления в породах почвы горных выработок, как правило, приурочены к глинистым прослойкам и слоям в соляных породах, поэтому предполагается, что геомеханической предпосылкой проявления ГДЯ является раскрытие глинистых контактов, что приводит к образованию каналов миграции свободных газов и формированию техногенных газонасыщенных зон под воздействием горных работ.

Постановка задачи включает задание параметров обрушения пород кровли отрабатываемого Третьего калийного пласта, локализацию пластических деформаций во вмещающих породах, раскрытие глинистых контактов в соляной толще. При этом учитывается, что обрушенные породы кровли лавы заполняют выработанное пространство и с учетом разуплотнения формируют техногенную геосреду, которая также включается в расчетную схему математического моделирования. Для определения напряженно-деформированного состояния пород используется модель идеальной упругопластичной среды с внутренним трением. При этом глинистые прослои описываются контактными элементами Гудмана.

По результатам решения ряда модельных задач в двумерной постановке делается вывод о существенном влиянии глинистых прослоев в почве отрабатываемого пласта на возможность реализации газодинамических явлений. Установлено, что при наличии трех глинистых контактов и более в слое подстилающей каменной соли создаются условия для формирования многоярусного очага ГДЯ, образовавшегося при раскрытии газонасыщенных глинистых контактов. Отмечается периодический характер формирования очагов ГДЯ при движении фронта очистных работ.
\end{abstract}

Aleksandr A. Baryakh (Author ID in Scopus: 670185281) - Doctor of Engineering, Professor, Corresponding Member of the Russian Academy of Sciences, Director (tel.: +00734221609 48, e-mail: bar@mi-perm.ru)

Sergey S. Andreyko (Author ID in Scopus: 55922205900, 6506180352) - Doctor of Engineering, Professor, Head of the Department of Development of Fields of Mineral Sergey S. Andreyko (Author ID in Scopus: 55922205900, 6506180352) - Doctor
Recourses (tel.: +007 34221984 38, e-mail: ssa@mi-perm.ru). The contact person.

Anton K. Fedoseev (Author ID in Scopus: 23466660100) - PhD in Engineering, Research Fellow (tel.: +007 342 216 75 02, e-mail: rm_anton@mi-perm.ru)

Барях Александр Абрамович - доктор технических наук, профессор, член-корреспондент РАН, директор (тел.: +007 3422160948 , e-mail: bar@mi-perm.ru) Андрейко Сергей Семенович - доктор технических наук, профессор, заведующий кафедрой разработки месторождений полезных ископаемых (тел.: +007 3422198438, e-mail: ssa@mi-perm.ru). Контактное лицо для переписки.

Федосеев Антон Кимович - кандидат технических наук, научный сотрудник (тел.: +007 34221675 02, e-mail: rm_anton@mi-perm.ru)

${ }^{1}$ The work has been done with financial support of the grand of the Goverment of the Russian Federation (Contract No. 14B25.31.0006 dated June 24, 2013) and the Project of the Mining Institute of the Presidium of the Ural Branch of the Russian Academy of Sciences "Study of mechanisms of destruction of rocks and saturated with gas massifs". 


\section{Introduction}

Development of deposits of potassium salts is significantly complicated by gas-dynamic phenomena (GDP) that in most cases cause significant cost damage to potash enterprises and pose a real threat to the life of miners. Over the past three decades, there was a significant contribution brought to the study of nature, mechanism, development of forecast methods and methods for preventing GDP in potash mines [1-10] and coal mines [11-15]. However, during the development of potash deposits new types of GDP are araised that were unknown in the mining practice previously. For example, sudden powerful emissions of salt and gas at the interface of the long face-drift during the layer excavation of potash formations in the conditions of the Starobinskoe deposit of potassium salts [16-19]. Due to the mentioned facts, there was an urgent need to study this type of GDP and develop possible methods to control gas dynamic processes in bedrocks of mine excavations.

Gas dynamic phenomena occur in presence of gas accumulations in a contour part of the rock massif and fulfillment of the main destruction criteria [20-26]. For the conditions of the Starobinskoe deposit of potassium salts, gas accumulations in rock formations of mine excavations are usually confined to clay interlayers and layers in salt rocks [27-28]. Geomechanical reasons for GDP to occure are opening of clay contacts, that leads to the formation of channels for migration of free gases and formation of artificial zones saturated with gas under the influence of mining operations.

\section{Problem statement}

In order to assess the danger of development of GDP geomechanical modeling of the stress strain state of bedrocks was performed. Samples of a bedrock of the developed long face space during the mining of layers 2, 2-3, 3 under the conditions of layer excavation of the Third formation are used as a material for modelling. Areas potentially dangerous for bedrock gas-dynamic phenomena were identified.

In general, this problem requires spatial mathematical modeling of the stress-strain state (SSS) of the salt rock massif. However, in order to understand the regularities of geomechanical processes (collapse of roof rocks of a mining formation, localization of plastic deformations in the enclosing rocks, opening of clay contacts in salt strata) that occur during the movement of a long face, and determine the degree of influence of the mechanical properties of rocks and technological parameters of cleaning on change of SSS of the salt massif it is requires to solve a number of problems that can be carried out in a two-dimensional statement.

During the mining of a long face a twodimensional design scheme for estimating the change in a SSS of a rock massif is constructed perpendicular to the movement of the clearing front and corresponds to a typical geological section for the Starobinskoe deposit (Fig. 1).

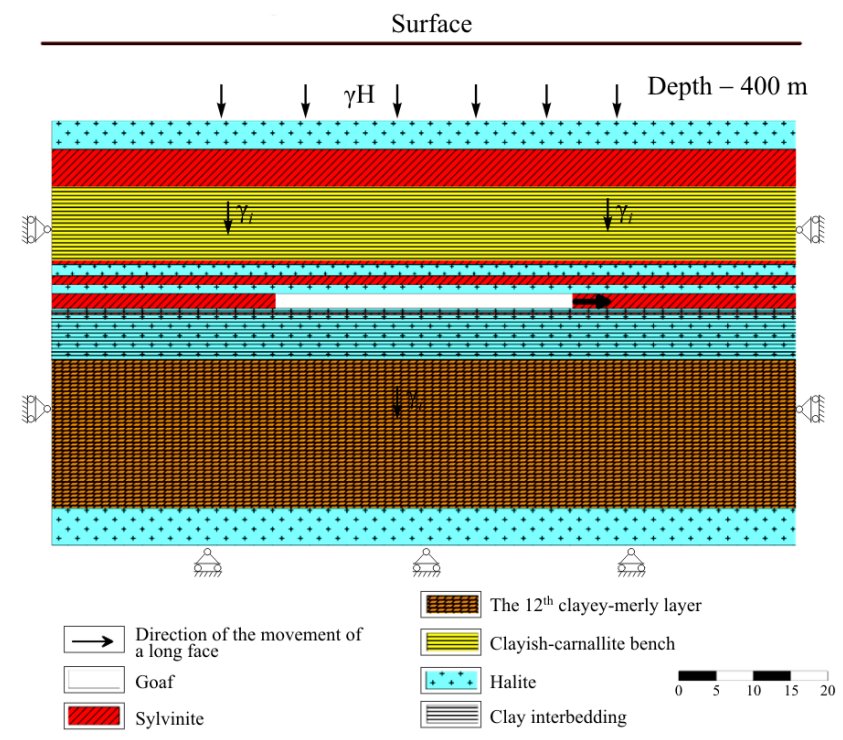

Fig. 1. Design scheme

Boundary conditions were set based on the initial lithostatic stress state of the upper part of the rock massif such as horizontal displacements on the lateral faces and vertical ones on the lower face were assumed to be zero. At the upper boundary, the rock pressure was assigned equal to the weight of the overlying rock mass. A calculated region was under the action of mass forces by intensity $\gamma_{i}$ (specific gravity).

In order to determine the rock SSS an ideal elastoplastic medium with internal friction was used. Parabolic envelope of Mohr circles was used as a plasticity condition in the compression region [29]. Localization of plastic deformations was possible with the fulfillment of the equation 


$$
\begin{gathered}
\tau_{\max }=\tau^{*}= \\
=\sqrt{\left(\sigma_{p}+\sigma\right)\left[2 \sigma_{p}-2 \sqrt{\sigma_{p}\left(\sigma_{p}+\sigma_{c}\right)}+\sigma_{c}\right]},
\end{gathered}
$$

and in the stretching region by the equation

$$
\sigma_{1}=\sigma_{\mathrm{p}}
$$

where $\tau_{\max }$ is for maximum tangential stress, $\tau_{\max }=\left(\sigma_{1}-\sigma_{3}\right) / 2 ; \sigma$ is for normal stress, $\sigma=\left(\sigma_{1}+\sigma_{3}\right) / 2 ; \sigma_{\mathrm{c}}$ is for compressive strength, $\sigma_{\mathrm{p}}$ is for ultimate tensile strength; $\sigma_{1}, \sigma_{3}$ are for the main stresses determined by results of mathematical modeling.

It has to be noted that zones of localization of plastic deformations were identified with processes of crack formation due to the development of shear and tear cracks respectively. A numerical solution of the problem was carried out by a standard procedure of the finite element method [30]. To take into account plastic nature of rock deformation a secant matrix method was used [31].

Strength and deformation properties of elements of the geological section taken into account are presented in the table 1 .

Table 1

Mechanical properties of rocks taken for calculation

\begin{tabular}{|l|c|c|c|}
\hline \multicolumn{1}{|c|}{ Rock } & $\begin{array}{c}\text { Deformation } \\
\text { modulus, GPa }\end{array}$ & $\begin{array}{c}\text { Compressive } \\
\text { strength, MPa }\end{array}$ & $\begin{array}{c}\text { Tensile } \\
\text { strength*, MPa }\end{array}$ \\
\hline Silvinite & 2.3 & 27 & 3 \\
\hline Halite & 2.3 & 27 & 3 \\
\hline Carnallite & 1.8 & 11 & 1 \\
\hline $\begin{array}{l}\text { Clayey-marly } \\
\text { layer }\end{array}$ & 0.82 & 11 & 3 \\
\hline
\end{tabular}

Note. ${ }^{*}$ In case of no experimental data the ultimate tensile strength is assumed different by an order of magnitude from the compressive strength limit.

Tensile strength of rocks is much lower than their compression characteristics. Therefore, localization of tensile forces in any area of the massif is a prerequisite for rock destruction. At the same time, it is obvious that rocks destroyed under the action of tensile stresses will not collapse into the goaf space if they are surrounded by material that has not lost its bearing capacity. From that, the first condition for collapse of rocks was the exit of the zone of action of tensile stresses to the outcrop. Modelling of the process was performed by means of a special organization of the computational iterative process which include steps that are as follows: at each iteration finite elements that were adjacent to the boundary of the roof of a goaf space of regions of tensile stresses concentration were eliminated (nullified) [32].

Presence of clay interbedding in the roof of a long face is an additional factor that contribute to rock collapse. In this case, when the region of shear fracturing reaches the "open" clay contact, rocks collapse into the goaf space [33]. That criteria of rock collapse is considered by the calculation procedure through localization and then elimination from the calculations the areas bounded by the "open" clay interbedding and zones of shear fracturing.

Collapsed rocks from the roof of a long face fill the goaf space and, taking into account their decompaction form an anthropogenic geoenvironment, which was also included in the calculation scheme of mathematical modeling. Its deformation properties were taken by an order of magnitude lower than the corresponding parameters of the rock massif.

Deformation of clay contacts between layers was described by Goodman's contact elements [34, 35]. The properties of clay contacts were taken from the data of laboratory studies [36] and are presented in the Table 2.

\begin{tabular}{|c|c|c|c|c|c|c|}
\hline 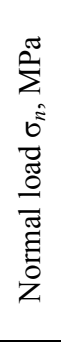 & 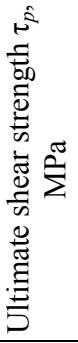 & 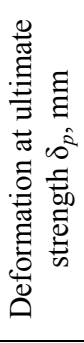 & 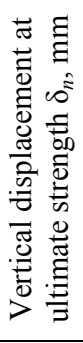 & 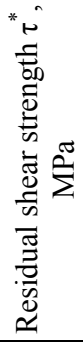 & 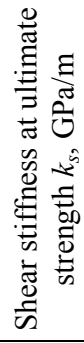 & 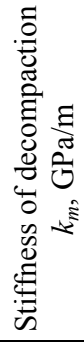 \\
\hline 2 & 1.60 & 0.98 & 0.14 & 1.29 & 1.63 & 0.06 \\
\hline 3.5 & 2.17 & 1.21 & 0.29 & 1.79 & 1.79 & 0.08 \\
\hline 5 & 2.93 & 1.27 & 0.25 & 2.62 & 2.31 & 0.13 \\
\hline 10 & 5.12 & 2.00 & 0.51 & 4.91 & 2.57 & 0.10 \\
\hline
\end{tabular}

Table 2

Mean mechanical properties of clay contacts

Note. Mean value of adhesion coefficient $C$ on the clay contact is $0.7 \mathrm{MPa}$, the angle of internal friction $\varphi$ is $23^{\circ}$.

\section{Results of mathematical modeling}

Clay contacts significantly influence the nature of the destruction bedrocks of the goaf space. These effects are most clear in conditions of minimal bedrock loading by collapsed rocks (Fig. 2). Thus, if 
there are no contacts or conditions for their opening, the unloading zone (Fig. $2 a$ ) covers a considerable part of the bedrock of the goaf space. That allows to degas this part of the bedrock. If there are three clay interbedding in a bedrock of a long face (Fig. $2 b$ )

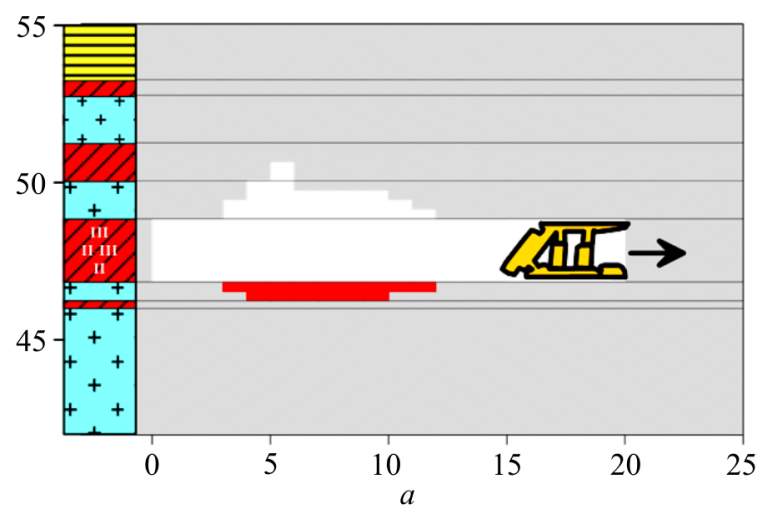

Face suppor

$\rightarrow$ Direction of the movement of a long face

$\square$ Goaf

EIA Sylvinite

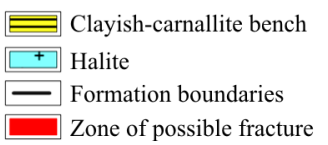

Fig. 2. Influence of clay contacts in a bedrock of a long face on change in SSS around the goaf space when moving away from an assembling drift
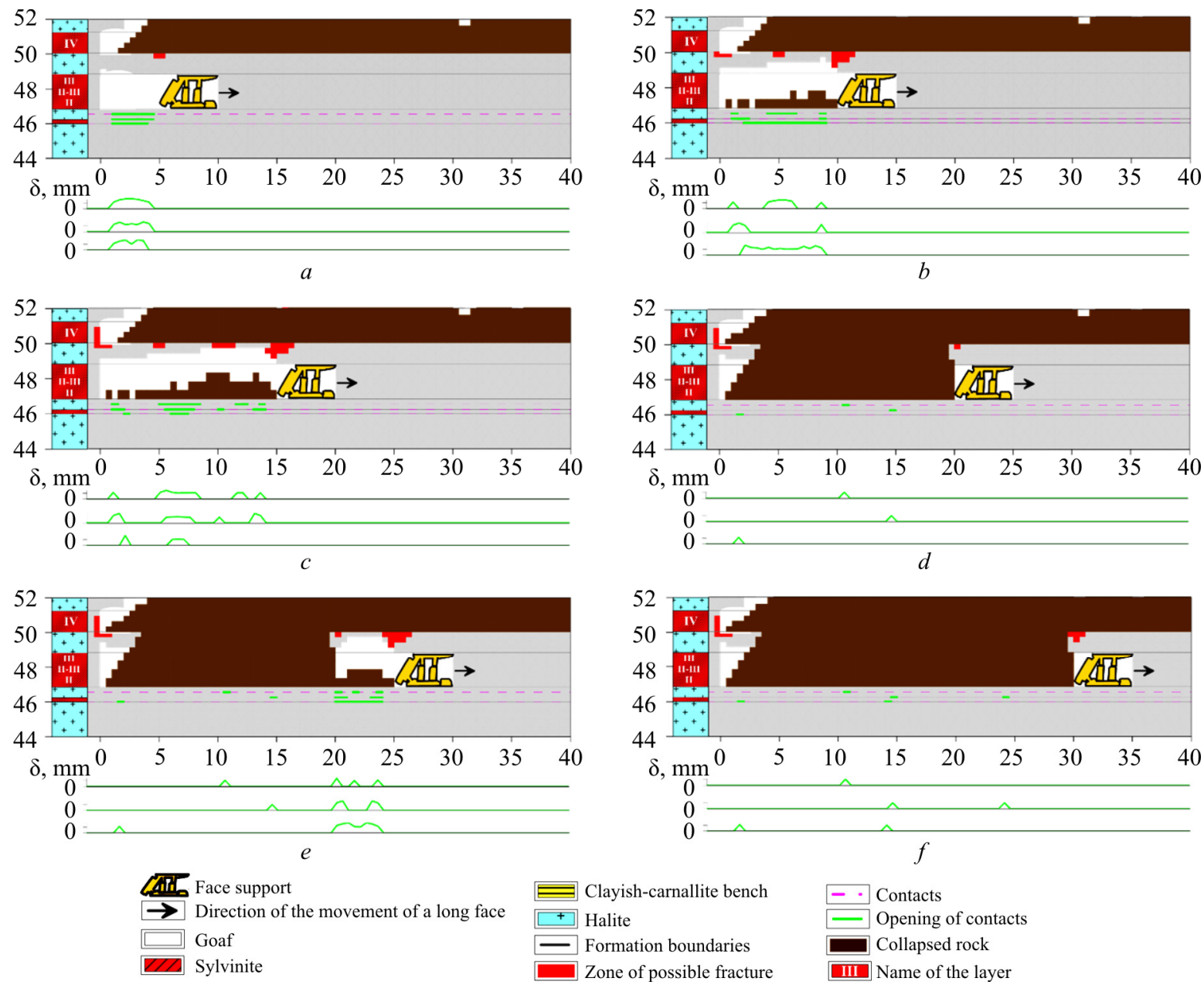

Fig. 3. Behaviour of destruction of the rock massif during the movement of the cleaning front with a length of a long face equal to: $a-5 \mathrm{~m} ; b-10 \mathrm{~m} ; c-15 \mathrm{~m} ; d-20 \mathrm{~m} ; e-25 \mathrm{~m} ; f-30 \mathrm{~m}$ 
The Fig. 3 shows the change in configuration of a rock massif when a long face move away the assembly drift during the mining of layers 2, 2-3, 3 in a section perpendicular to the cleaning front. Localization and amplitude of opening of the clay contacts are shown as well. Contacts in the roof are degassed as a result of mining, therefore only the state of the clay interbedding developed in a bedrock of a long face is analyzed. Opening of clay contacts is observed immediately during the movement of cleaning works front (Fig. 3a). If the length of a goaf behind the support is $10 \mathrm{~m}$ and more then the roof starts to collapse and contacts partially close (Fig. $3 b$, $3 c$ ). In case a long face moves away from the the assembly drift then there is a destruction of interbedding and penetration of rocks collapsed during rock roof mining into the goaf backfilling (Fig. 3d). Rocks create an additional resistance which leads to the closure or degassing of contacts in the long face bedrock (see Fig. 3d) [37]. In some cases, collapse of the roof behind the face support does not take place immediately $[38,39]$. That leads to the opening of contacts in a goaf bedrock and hence, create conditions for GDP occurrence (Fig. 3e). That contacts are closed after long face movement and collapse of rocks in the space behind the support (Fig. 3f). Thus, depending on physical and mechanical properties of the rocks, their decompaction and lateral variability of these characteristics as well, a certain periodicity in the character of the destruction of the rock mass in the area of the goaf space can be observed. At the same time there are focuses of GDP formed periodically in the face space of a long face due to the opening of contacts in a bedrock (see Fig. $3 d, 3 e, 3 f$ ).

\section{Conclusion}

Results of mathematical modeling of a stressstrain state of bedrock during the mining layers 2, 2-3 and 3 under the conditions of the layer excavation of the Third layer allowed drawing the following conclusions:

1. It was established that there is an unloading area in a long face bedrock (underlying halite layer) in case when the bedrock does not contain clay inerlayers and the long face moves away from the assemly drift. There is no contact accumulations of free gas in the bedrock formed under mentioned conditions.

2. It is established that if there are three or more clay contacts in the layer of the underlying halite then early opening of the contacts occurs. Overlapping rocks retain their continuity. Thus, conditions for the formation of a multilevel focus of the GDP formed during the discovery of gassaturated clay contacts are created.

3. Temporary focuses of GDP can be periodically formed in the bedrock in case of roof overhang during the motion of the clearing front in the face space.

The results of conducted studies were used to develop parameters of preventive drilling of degassing holders in the bedrock of mines. That allows to prevent gas-dynamic phenomena to occure from the bedrock during the processing of layers 2, 2-3 and 3 while implementation of various bord and pillar methods to develope the Third potash formation at mines of 1-4 RU and Krasnoslobodskiy mine 2 RU of Belaruskali JSC.

\section{References}

1. Kovalev O.V. Bor'ba s gazodinamicheskimi iavleniiami na kaliinykh rudnikakh [Combating gasdynamic phenomena at potash mines]. Bezopasnost' truda $v$ promyshlennosti, 1980, no.6, pp.51-53.

2. Duchrow G. The production of potash in East Germany. Glueckauf, 1990, vol.126, no.21/22, pp.1016-1033.

3. Duchrow G. Der 100-jährige "Rhönmarsch" in die kohlensäurefelder des südthüringischen kalibergbaus. Zeitschrift für Kunst und Kultur im Bergba, 1997, no.49(4), pp.123-147.

4. Cruickshank N.M., Mahtab M.A., Wane M.T. Methods for predicting gas outburst in salt and coal mines. Metallurgical and Petroleum Engineers, 1986, vol.280, iss.pt A, pp.2079-2084.

5. Andreiko S.S., Blium M.F., Zemskov A.N. Problemy bezopasnosti gornykh rabot na rudnikakh PO "Belarus'kalii" v usloviiakh gazovydelenii i gazodinamicheskikh iavlenii [Problems of safety of mining operations at the mines of PA "Belaruskaliy" in conditions of gas evolution and gas dynamic phenomena]. Gornyi zhurnal, 1998, no.11-12, pp.88-92.

6. Chuzhov V.N., Andreiko S.S. Gazodinamicheskie iavleniia iz pochvy gornykh vyrabotok $\mathrm{v}$ kaliinykh rudnikakh [Gas-dynamic phenomena from the soil of mine workings in potash mines]. Gornaia mekhanika, 2001, no.1-2, pp.26-30.

7. Prushak V.Ia., Shcherba V.Ia., Andreiko S.S. Analiz geologicheskikh uslovii vozniknoveniia gazodinamicheskikh iavlenii na Starobinskom mestorozhdenii kaliinykh solei [Analysis of the geological conditions of occurrence of gas-dynamic phenomena at the Starobinsky deposit of potassium salts]. Gornaia mekhanika i mashinostroenie, 2002, no.1, pp.89-94.

8. Andreiko S.S., Chistiakov A.N., Beresnev S.P. Sostoianie i perspektivy resheniia problemy gazodinamicheskikh iavlenii $\mathrm{v}$ kaliinykh rudnikakh na Verkhnekamskom i Starobinskom mestorozhdeniiakh kaliinykh solei [State and prospects for the solution of the 
problem of gas dynamic phenomena in potash mines at the Verkhnekamsk and Starobinsky deposits of potash salts]. Gornaia mekhanika, 2006, no.2, pp.66-72.

9. Andreiko S.S., Ivanov O.V., Nesterov E.A. Bor'ba s gazodinamicheskimi iavleniiami pri razrabotke Verkhnekamskogo i Starobinskogo mestorozhdenii kaliinykh solei [Combating gas-dynamic phenomena in the development of the Verkhnekamsk and Starobin deposits of potash salts]. Nauchnye issledovaniia i innovatsii, 2009, vol.3, no.4, pp.34-37.

10. Shcherba V.Ia., Andreiko S.S., Nekrasov S.V., Prushak V.Ia., Zubovich V.S. Predotvrashchenie gazodinamicheskikh iavlenii $\mathrm{V}$ pochve vyrabotannogo prostranstva lav [Prevention of gas-dynamic phenomena in the soil of the developed space of long faces]. Gornyi zhurnal, 2004, no.2, pp.45-48.

11. Li S., Zhang T. Catastrophic mechanism of coal and gas outbursts and their prevention and control. Mining Science and Technology (China), 2010, vol.20, iss.2, pp.209-214. DOI: 10.1016/S1674-5264(09)60186-1

12. María B., Aguado D., González Nicieza C. Control and prevention of gas outbursts in coal mines, Riosa-Olloniego coalfield, Spain. International Journal of Coal Geology, 2010, vol.69, iss.4, pp.253-266. DOI: 10.1016/j.coal.2006.05.004

13. Toraño J., Torno S., Alvarez E., Riesgo P. Application of outburst risk indices in the underground coal mines by sublevel caving. International Journal of Rock Mechanics and Mining Sciences, 2012, vol. 50, pp.94-101. DOI: 10.1016/j.ijrmms.2012.01.005

14. Li Z., Wang E., Ou J., Liu Z. Hazard evaluation of coal and gas outbursts in a coal-mine roadway based on logistic regression model. International Journal of Rock Mechanics and Mining Sciences, 2015, vol.80, pp.185195. DOI: 10.1016/j.ijrmms.2015.07.006

15. Trubetskoi K.N., Iofis M.A., Esina E.N. Osobennosti geomekhanicheskogo obespecheniia osvoeniia mestorozhdenii, sklonnykh $\mathrm{k}$ gazodinamicheskim iavleniiam [Features of geomechanical support for the development of deposits prone to gas dynamic phenomena]. Fizikotekhnicheskie problemy razrabotki poleznykh iskopaemykh, 2015, no.3, pp.64-71.

16. Andreiko S.S., Petrovskii B.I., Andreiko L.V. Metody prognoza i sposoby predotvrashcheniia gazodinamicheskikh iavlenii iz pochvy gornykh vyrabotok v rudnikakh PO "Belarus'kalii" [Methods of forecasting and ways to prevent gas-dynamic phenomena from the soil of mine workings in the mines of PO "Belaruskali"]. Gornaia mekhanika, 1998, no.1, pp.29-35.

17. Prushak V.Ia., Shcherba V.Ia., Andreiko S.S. Analiz geologicheskikh uslovii vozniknoveniia gazodinamicheskikh iavlenii na Starobinskom mestorozhdenii kaliinykh solei [Analysis of the geological conditions of occurrence of gas-dynamic phenomena at the Starobinsky deposit of potassium salts]. Gornaia mekhanika i mashinostroenie, 2002, no.1, pp.89-94.

18. Shcherba V.Ia., Tukhto A.A., Andreiko S.S, Zubovich V.S. Mekhanizm obrazovaniia svobodnogo gaza $\mathrm{v}$ ochagakh gazodinamicheskikh iavlenii kaliinykh rudnikov [Mechanism of formation of free gas in the foci of gas-dynamic phenomena of potash mines]. Gornyi zhurnal, 2004, no.3, pp.64-67.
19. Kutyrlo V.E. Gazodinamicheskie iavleniia v promyshlennykh gorizontakh Starobinskogo mestorozhdeniia kaliinykh solei [Gas-dynamic phenomena in the industrial horizons of the Starobinsky deposit of potassium salts]. Litosfera, 2007, no.1, pp.140-148.

20. Andreiko S.S., Lialina T.A., Ivanov O.V., Nesterov E.A. Opredelenie kriticheskoi velichiny gazovogo davleniia, sposobnogo vyzvat' gazodinamicheskie iavleniia pri razrabotke sil'vinitovogo plasta [Determination of the critical value of the gas pressure, which can cause gas dynamic phenomena in the development of the sylvinite layer]. Izvestiia vysshikh uchebnykh zavedenii. Gornyi zhurnal, 2013, no.5, pp.22-28.

21. Zubov V.P., Smychnik A.D. Vnezapnye vybrosy soli i gaza na kaliinykh rudnikakh i ikh preduprezhdenie [Sudden emissions of salt and gas in potash mines and their prevention]. Gornyi zhurnal, 1998, no.11-12, pp.85-87.

22. Han J., Zhang H.W., Li S., Song W.H. The characteristic of in situ stress in outburst area of China. Original Research Article Safety Science, 2012, vol.50, iss.4, pp.878-884. DOI: 10.1016/j.ssci.2011.08.014

23. Stormont J.C., Daemen J.R. Laboratory study of gas permeability changes in rock salt during deformations. International Journal of Rock Mechanics and Mining Sciences, 1992, geomech. abstr., 29, pp.325-342. DOI: 10.1016/0148-9062(92)90510-7

24. Popp T., Kern H., Schulze O. Evolution of dilatancy and permeability in rock salt during hydrostatic compaction and triaxial deformation. J. Geophys. Res., 2001, 106, no.B3, pp.4061-4078. DOI: 10.1029/2000JB900381

25. Podlesnyi I.A., Beresnev S.P., Andreiko S.S., Nekrasov S.V., Litvinovskaia N.A. Geomekhanicheskoe modelirovanie vnezapnykh razrushenii porod pochvy gornykh vyrabotok [Geomechanical modeling of sudden destruction of soil rocks of mine workings]. Gornyi zhurnal, 2010, no.8, pp. 28-30.

26. Tarakanov V.A., Golovatyi I.I., Beresnev S.P., Andreiko S.S., Ivanov O.V. Issledovaniia gazonosnosti porod plasta Tret'ego kaliinogo gorizonta Starobinskogo mestorozhdeniia [Studies of the gas content of the rocks of the third potash horizon of the Starobinsky deposit]. Gornyi zhurnal, 2010, no.8, pp.25-27.

27. Beresnev S.P., Seniuk V.V., Gonchar V.I., Andreiko S.S., Litvinovskaia N.A. Issledovanie mekhanizma formirovaniia opasnykh po gazodinamicheskim iavleniiam zon v porodakh kaliinogo gorizonta [Investigation of the mechanism of formation of zones dangerous in gas-dynamic phenomena in rocks of the potassium horizon]. Gornyi zhurnal, 2010, no.8, pp.31-33.

28. Litvinovskaia N.A. Gazonosnost' i gazodinamicheskie kharakteristiki porod pochvy pri sloevoi vyemke Tret'ego kaliinogo plasta v usloviiakh rudnikov OAO "Belarus'kalii" [Gas-bearing and gas-dynamic characteristics of the soil rocks with layered excavation of the Third potash stratum in the conditions of JSC "Belaruskali"]. Strategiia $i$ protsessy osvoeniia georesursov. Sbornik nauchnykh trudov. Perm', Gornyi institut Ural'skogo otdeleniia Rossiiskoi akademii nauk, 2016, iss.14, pp.255-258.

29. Kuznetsov G.N. Mekhanicheskie svoistva gornykh porod [Mechanical properties of rocks]. Moscow, Ugletekhizdat, 1947, 180 p. 
30. Zienkiewich O.C. The finite element method in engineering science. London, Mcgraw-Hill, 1971, 521 p.

31. Fadeev A.B. Metod konechnykh elementov v geomekhanike [Finite element method in geomechanics]. Moscow, Nedra, 1987, 221 c.

32. Baryakh A.A., Fedoseev A.K. Sinkhole formation mechanism. Journal of Mining Science, 2011, vol.47, iss.6, pp.404-412. DOI: 10.1134/S1062739147040022

33. Bariakh A.A., Shumikhina A.Iu., Toksarov V.N., Lobanov S.Iu., Evseev A.V. Kriterii i osobennosti razrusheniia sloistoi krovli kamer pri razrabotke Verkhnekamskogo mestorozhdeniia kaliinykh solei [Criteria and features of destruction of layer roof chambers in the development of the Verkhnekamsk deposit of potassium salts]. Gornyi zhurnal, 2011, no.11, pp.15-19.

34. Goodman R.E. The mechanical properties of joints. Advances in rock mechanics: proceedings of the Third Congress of the International Society for Rock Mechanics. Denver, 1974, vol.1, part A, pp.127-140.

35. Groth T. Description and applicability of the BEFEM code. Appl. Rock Mech. Mining. Proc. Conf. Lulea. London, 1981, pp.204-208. DOI: $10.1016 / 0148-9062(82) 90977-9$
36. Baryakh A.A., Dudyrev I.N., Asanov V.A., Pan'kov I.L. Interaction of layers in salt deposit. 1. Mechanical properties of joints. Journal of Mining Science, 1992, vol.28, iss.2, pp.145-149. DOI: 10.1007/BF00710733

37. Gubanov V.A., Poliakov A.L., Shcherba V.Ia. Issledovanie kharaktera vosstanovleniia nagruzki na pochvu lavy pozadi ochistnogo zaboia posle vyemki verkhnego sloia $\mathrm{v}$ usloviiakh tret'ego gorizonta PO "Belarus'kalii" [Investigation of the nature of restoration of the load on the long face bedrock behind the face after excavation of the upper layer under the conditions of the third horizon of PO "Belaruskali"]. Gornyi zhurnal, 2002, no.3-4, pp.39-40.

38. JinFeng Ju, Jialin Xu. Structural characteristic of key strata and strata behavior of a fully mechanized longwall face with $7.0 \mathrm{~m}$ height chocks. International Journal of Rock Mechanics and Mining Sciences, 2013, vol.58, pp.46-54. DOI: 10.1016/j.ijrmms.2012.09.006

39. Gubanov V.A. O mekhanizme obrusheniia porod krovli pri sloevoi vyemke Tret'ego kaliinogo plasta [On the mechanism of collapse of the roof rocks with the layering of the Third potash stratum]. Gornyi zhurnal, 2002, no.3-4, pp.50-64.

\section{Библиографический список}

1. Ковалев О.В. Борьба с газодинамическими явлениями на калийных рудниках // Безопасность труда в промышленности. - 1980. - № 6. - С. 51-53.

2. Duchrow G. The production of potash in East Germany // Glueckauf. - 1990. - Vol. 126, № 21/22. P. 1016-1033.

3. Duchrow G. Der 100-jährige "Rhönmarsch" in die Kohlensäurefelder des Südthüringischen Kalibergbaus // Zeitschrift für Kunst und Kultur im Bergbau. - 1997. № 49 (4). - S. 123-147.

4. Cruickshank N.M., Mahtab M.A., Wane M.T. Methods for predicting gas outburst in salt and coal mines // Metallurgical and Petroleum Engineers. - 1986. Vol. 280, iss. part A. - P. 2079-2084.

5. Андрейко С.С., Блюм М.Ф., Земсков А.Н. Проблемы безопасности горных работ на рудниках ПО «Беларуськалий» в условиях газовыделений и газодинамических явлений // Горный журнал. - 1998. № 11-12. - С. 88-92.

6. Чужов В.Н., Андрейко С.С. Газодинамические явления из почвы горных выработок в калийных рудниках // Горная механика. - 2001. - № 1-2. C. $26-30$.

7. Прушак В.Я., Щерба В.Я., Андрейко С.С. Анализ геологических условий возникновения газодинамических явлений на Старобинском месторождении калийных солей // Горная механика и машиностроение. - 2002. - № 1. - С. 89-94.

8. Андрейко С.С., Чистяков А.Н., Береснев С.П. Состояние и перспективы решения проблемы газодинамических явлений в калийных рудниках на Верхнекамском и Старобинском месторождениях калийных солей // Горная механика. - 2006. - № 2. - С. 66-72.

9. Андрейко С.С., Иванов О.В., Нестеров Е.А. Борьба с газодинамическими явлениями при разработке Верхнекамского и Старобинского месторождений калийных солей // Научные исследования и инновации. -
Пермь: Изд-во Перм. нац. исслед. политехн. ун-та, 2009. - Т. 3, № 4. - С. 34-37.

10. Предотвращение газодинамических явлений в почве выработанного пространства лав / В.Я. Щерба, С.С. Андрейко, С.В. Некрасов, В.Я. Прушак, В.С. Зубович // Горный журнал. - 2004. - № 2. - С. 45-48.

11. Li S., Zhang T. Catastrophic mechanism of coal and gas outbursts and their prevention and control // Mining Science and Technology (China). - 2010. - Vol. 20, iss. 2. P. 209-214. DOI: 10.1016/S1674-5264(09)60186-1

12. María B., Aguado D., González Nicieza C. Control and prevention of gas outbursts in coal mines, Riosa-Olloniego coalfield, Spain // International Journal of Coal Geology. - 2010. - Vol. 69, iss. 4. - P. 253-266. DOI: $10.1016 /$ j.coal.2006.05.004

13. Application of outburst risk indices in the underground coal mines by sublevel caving / J. Toraño, S. Torno, E. Alvarez, P. Riesgo // International Journal of Rock Mechanics and Mining Sciences. - 2012. Vol. 50. - P. 94-101. DOI: 10.1016/j.ijrmms.2012.01.005

14. Hazard evaluation of coal and gas outbursts in a coal-mine roadway based on logistic regression model / Z. Li, E. Wang, J. Ou, Z. Liu // International Journal of Rock Mechanics and Mining Sciences. - 2015. - Vol. 80. P. 185-195. DOI: 10.1016/j.ijrmms.2015.07.006

15. Трубецкой К.Н., Иофис М.А., Есина Е.Н. Особенности геомеханического обеспечения освоения месторождений, склонных к газодинамическим явлениям // Физико-технические проблемы разработки полезных ископаемых. - 2015. - № 3. - С. 64-71.

16. Андрейко С.С., Петровский Б.И., Андрейко Л.В. Методы прогноза и способы предотвращения газодинамических явлений из почвы горных выработок в рудниках ПО «Беларуськалий» // Горная механика. - 1998. - № 1. - С. 29-35.

17. Прушак В.Я., Щерба В.Я., Андрейко С.С. Анализ геологических условий возникновения 
газодинамических явлений на Старобинском месторождении калийных солей // Горная механика и машиностроение. - 2002. - № 1. - С. 89-94.

18. Механизм образования свободного газа в очагах газодинамических явлений калийных рудников / В.Я. Щерба, А.А. Тухто, С.С. Андрейко, В.С. Зубович // Горный журнал. - 2004. - № 3. - С. 64-67.

19. Кутырло В.Э. Газодинамические явления в промышленных горизонтах Старобинского месторождения калийных солей // Літасфера. - 2007. - № 1. - С. 140-148.

20. Определение критической величины газового давления, способного вызвать газодинамические явления при разработке сильвинитового пласта / С.С. Андрейко, Т.А. Лялина, О.В. Иванов, Е.А. Нестеров // Известия вузов. Горный журнал. - 2013. - № 5. - С. 22-28.

21. Зубов В.П., Смычник А.Д. Внезапные выбросы соли и газа на калийных рудниках и их предупреждение // Горный журнал. - 1998. - № 11-12. - С. 85-87.

22. The characteristic of in situ stress in outburst area of China / J. Han, H.W. Zhang, S. Li, W.H. Song // Original Research Article Safety Science. - 2012. - Vol. 50, iss. 4. P. 878-884. DOI: 10.1016/j.ssci.2011.08.014

23. Stormont J.C., Daemen J.R. Laboratory study of gas permeability changes in rock salt during deformations // International Journal of Rock Mechanics and Mining Sciences. - 1992. - Geomech. abstr., 29. - P. 325-342. DOI: 10.1016/0148-9062(92)90510-7

24. Popp T., Kern H., Schulze O. Evolution of dilatancy and permeability in rock salt during hydrostatic compaction and triaxial deformation // J. Geophys. Res. - 2001. - 106, № B3. - P. 4061-4078. DOI: 10.1029/2000JB900381

25. Геомеханическое моделирование внезапных разрушений пород почвы горных выработок / И.А. Подлесный, С.П. Береснев, С.С. Андрейко, С.В. Некрасов, Н.А. Литвиновская // Горный журнал. 2010. - № 8. - С. 28-30.

26. Исследования газоносности пород пласта Третьего калийного горизонта Старобинского месторождения / В.А. Тараканов, И.И. Головатый, С.П. Береснев, С.С. Андрейко, О.В. Иванов // Горный журнал. - 2010. - № 8. - С. 25-27.

27. Исследование механизма формирования опасных по газодинамическим явлениям зон в породах калийного горизонта / С.П. Береснев, В.В. Сенюк, В.И. Гончар, С.С. Андрейко, Н.А. Литвиновская // Горный журнал. - 2010. - № 8. - С. 31-33.
28. Литвиновская Н.А. Газоносность и газодинамические характеристики пород почвы при слоевой выемке Третьего калийного пласта в условиях рудников ОАО «Беларуськалий» // Стратегия и процессы освоения георесурсов: сб. науч. тр. - Пермь: Изд-во Горн. ин-та УрО РАН, 2016. - Вып. 14. C. $255-258$.

29. Кузнецов Г.Н. Механические свойства горных пород. - М.: Углетехиздат, 1947. - 180 с.

30. Zienkiewich O.C. The finite element method in engineering science. - London: Mcgraw-Hill, 1971. - 521 p.

31. Фадеев А.Б. Метод конечных элементов в геомеханике. - М.: Недра, 1987. - 221 с.

32. Baryakh A.A., Fedoseev A.K. Sinkhole formation mechanism // Journal of Mining Science. - 2011. - Vol. 47, iss. 6. - P. 404-412. DOI: 10.1134/S1062739147040022

33. Критерии и особенности разрушения слоистой кровли камер при разработке Верхнекамского месторождения калийных солей / А.А. Барях, А.Ю. Шумихина, В.Н. Токсаров, С.Ю. Лобанов, А.В. Евсеев // Горный журнал. - 2011. - № 11. - С. 15-19.

34. Goodman R.E. The mechanical properties of joints // Advances in rock mechanics: proceedings of the Third Congress of the International Society for Rock Mechanics. Denver, 1974. - Vol. 1, part A. - P. 127-140.

35. Groth T. Description and applicability of the BEFEM code // Appl. Rock Mech. Mining. Proc. Conf. Lulea. - London, 1981. - P. 204-208. DOI: 10.1016/01489062(82)90977-9

36. Interaction of layers in salt deposit. 1. Mechanical properties of joints / A.A. Baryakh, I.N. Dudyrev, V.A. Asanov, I.L. Pan'kov // Journal of Mining Science. - 1992. - Vol. 28, iss. 2. - P. 145-149. DOI: 10.1007/BF00710733

37. Губанов В.А., Поляков А.Л., Щерба В.Я. Исследование характера восстановления нагрузки на почву лавы позади очистного забоя после выемки верхнего слоя в условиях третьего горизонта ПО «Беларуськалий» // Горный журнал. - 2002. - № 3-4. - С. 39-40.

38. JinFeng Ju, Jialin Xu. Structural characteristic of key strata and strata behavior of a fully mechanized longwall face with $7.0 \mathrm{~m}$ height chocks // International Journal of Rock Mechanics and Mining Sciences. - 2013. - Vol. 58. P. 46-54. DOI: 10.1016/j.ijrmms.2012.09.006

39. Губанов В.А. О механизме обрушения пород кровли при слоевой выемке Третьего калийного пласта // Горный журнал. - 2002. - № 3-4. - С. 50-64.

Please cite this article in English as:

Baryakh A.A., Andreyko S.S., Fedoseev A.K. About the mechanism of localization of gas dynamic phenomena focuses in the bedrock of sylvinite formations. Perm Journal of Petroleum and Mining Engineering, 2017, vol.16, no.3, pp.247-254. DOI: 10.15593/2224-9923/2017.3.5

Просьба ссылаться на эту статью в русскоязычных источниках следующим образом:

Барях А.Б., Андрейко С.С., Федосеев А.К. О механизме локализации очагов газодинамических явлений в почве сильвинитовых пластов // Вестник Пермского национального исследовательского политехнического университета. Геология. Нефтегазовое и горное дело. - 2017. - Т.16, №3. - С.247-254. DOI: 10.15593/2224-9923/2017.3.5 